Trinity University

Digital Commons @ Trinity

Philosophy Faculty Research

Philosophy Department

Fall 2007

\title{
Against Them, Too: A Reply to Alward
}

Andrew Kania

Trinity University, akania@trinity.edu

Follow this and additional works at: https://digitalcommons.trinity.edu/phil_faculty

Part of the Philosophy Commons

\section{Repository Citation}

Kania, A. (2007). Against them, too: A reply to Alward. The Journal of Aesthetics and Art Criticism, 65(4), 404-408. doi:10.1111/j.1540-594X.2007.00274.x

This Post-Print is brought to you for free and open access by the Philosophy Department at Digital Commons @ Trinity. It has been accepted for inclusion in Philosophy Faculty Research by an authorized administrator of Digital Commons@ Trinity. For more information, please contact jcostanz@trinity.edu. 


\section{Against Them, Too: Reply to Alward}

[This is the peer reviewed version of the following article: Andrew Kania,

“Against Them, Too: Reply to Alward” Journal of Aesthetics and Art Criticism

65 (2007): 404-8, which has been published in final form at

http://onlinelibrary.wiley.com/doi/10.1111/j.1540-594X.2007.00274.X/abstract.

This article may be used for non-commercial purposes in accordance with Wiley

Terms and Conditions for Self-Archiving. Please cite only the published version.]

In his defense of a version of what I have called 'the ubiquity thesis' - the idea that every narrative fiction contains an overarching fictional narrator - Peter Alward gives a helpful reconstruction of some of my arguments against that thesis and clearly lays out a part of the theoretical terrain on which this debate takes place. ${ }^{1}$ However, by the end of the piece he is offering solace to both me and those I was arguing against, which is about as close as philosophers come to fightin’ words.

Alward is in a position to offer solace to both sides in the original debate since he argues for a middle way. According to Alward, though it is not the case that there is a fictional narrator of every narrative fiction, there is a non-actual narrator of every narrative fiction. The non-actual comprises more than just the fictional, so some narrative fictions have fictional narrators, while others have non-actual narrators of another sort. Moreover, a work's narrator is always a fact-teller, on Alward's view. Thus, my solace is that the original ubiquity thesis is false, while my opponents' solace is that a close variant of it is true. Stories with ordinary first-person fictional narrators, reliable or otherwise, 
such as David Copperfield, are covered by Alward's new ubiquity thesis, as they were by the original ubiquity thesis - they have non-actual (fictional) fact-telling narrators. Stories that are narrated in a plain, omniscient third-person style, such as my central example of Graham Greene’s The Heart of the Matter, which I take simply to be told by their actual authors, and thus counterexamples to the original ubiquity thesis, Alward argues are not simply told by their authors, but are (also) narrated by some non-actual (but nonfictional), fact-telling agency.

There are two main concerns I have with Alward's view. One is with the nature of the new kind of narrator he appeals to - the non-actual, non-fictional fact-teller. The other is with his argument for the existence of such agents in all narrative fictions that do not have a fictional narrator. I will address Alward's argument first, and then the coherence of his alternative theory that non-actual, non-fictional, fact-telling narrators can do the work the original ubiquity theorists assigned to fictional narrators.

It is useful to approach Alward's category of non-actual, non-fictional fact-tellers by way of the category of non-actual, non-fictional fiction-tellers. He gives the example of the idealized author-figures invoked by some theories of interpretation. ${ }^{2}$ The sense in which these figures are non-actual is pretty obvious - you won't meet one of them on the street. But the sense in which they are non-fictional is less so. On the one hand, these figures are not part of the fictional world of the work. None of the work's characters will meet the implied author on any fictional street. ${ }^{3}$ But on the other hand, presumably what we are supposed to do when we engage with a work of fiction, according to these theories of interpretation, is something like to imagine an author with semantic intentions that would have been best carried out by the production of just such a work as the one in 
hand. This muddies the distinction between Alward's two categories of non-actual tellers, since if we ought to imagine a certain person, then that person is a fictional being, according to one popular theory of fiction. ${ }^{4}$ Nonetheless, perhaps the distinction between being and not being a member of the fictional world of the work is enough to ground the distinction to which Alward appeals.

Now, what is the argument that is supposed to convince us that a work of fiction must have a non-actual fact-telling narrator? Alward defends what he calls the 'doxastic argument'. We agree on its second premise: There are no actual fact-tellers of literary narratives. But we seem to disagree on its first premise. ${ }^{5}$ Alward believes that "[u]nderstanding a literary narrative requires the supposition that it is told by a factteller” (??). His argument for this premise appeals to the theory of pragmatic implicature. The maxim he uses as an illustration is one of Grice's maxims of quality: Do not say what you believe to be false. He points out that this maxim does not govern fiction-telling discourse because there is simply no expectation that fiction-tellers believe what they say; thus fictional-tellers simply cannot pragmatically impart anything by means of it. Only a fact-teller - who is obligated to say only what she believes - could generate implicatures by such means. As a result, if unexpressed fictional truths are generated by pragmatic implicature - and what other option is there? - then they can be discerned only by supposing (or imagining) that the text is told by a fact-teller.

There is an odd disconnection between the maxim Alward uses as an illustration and the aspect of our understanding of fiction that he focuses on. As Alward says, the nature of the fictional world of a particular work goes beyond "the propositions expressed by the 
sentences which constitute it” (??). Taking The Heart of the Matter as a central example again, it is true in the world of that work that the "bald pink knees" what Wilson thrusts against the ironwork at the beginning of the novel are in the middle of his legs, and not on his forehead (as the result of an unfortunate genetic condition that goes unmentioned throughout the rest of the novel), nor prostheses on sticks that he carries around for some troubling psychological reason. But this is not a matter of the maxim of quality Alward mentions. It is a matter of something like what Kendall Walton calls the Reality Principle:

If $p_{1} \ldots, p_{\mathrm{n}}$ are the propositions whose fictionality a representation generates directly, another proposition, $q$, is fictional in it if, and only if, were it the case that $p_{1} \ldots, p_{\mathrm{n}}$, it would be the case that $q .{ }^{6}$

Walton shows that this principle is defeasible, and that it is not sufficient as an answer to the question Alward raises - at the very least there are other principles in play, such as the Mutual Belief Principle that Walton goes on to discuss next. ${ }^{7}$ But Walton and others agree that some versions of these principles are clearly in play in our understanding of much fiction. Thus we have a pretty widely held alternative theory with which to respond to Alward's apparently rhetorical question: What option other than pragmatic implicature is there for the generation of unexpressed fictional truths? The Reality Principle, among others.

Alward notes that "[o]ne might, of course, argue that there are a separate set of conversational principles governing fiction-telling. But without independent evidence for such principles, this manoeuvre is ad hoc" (??, n. 22). The evidence is simply how we understand fictions, which is clearly different from how we understand non-fictional 
narratives. Some principles that govern our production of and interaction with fictions will doubtless be related to some principles of ordinary conversational pragmatic implicature. For instance, there is surely a fictional counterpart of the maxim of quality Alward mentions: Do not tell what the audience ought not to imagine. The Reality Principle itself seems to be related to the maxims of quantity: (i) Be as informative as required, and (ii) be no more informative than is required. ${ }^{8}$ And the whole enterprise is governed by a close variant of the Cooperative Principle: Make your linguistic contribution such as is required, at the stage at which it occurs, by the accepted purpose or direction of the discourse in which you are engaged. ${ }^{9}$ But despite these similarities, there is enough difference between the purpose and rules governing fictional discourse and conversation for the latter to require its own theory. Think only of the Mutual Belief Principle, which says that that is implicitly fictional which would be believed in the artist's culture to be implied by what is explicitly fictional. ${ }^{10}$ This is more distant from any rule of conversational implicature than the previous examples. Any theory of fiction which appeals to such principles will only count as ad hoc if it is posited to save a theory that does a worse job of explaining narrative fiction, all things considered, than Alward's.

So, I don't think Alward gives us a convincing argument for his revised ubiquity thesis. If you're not convinced by my criticisms of his argument, though, the view he is defending should give you pause. He claims that narrative fictions without fictional narrators at least have non-actual fact-telling narrators. That is, such fictions have narrators that occupy neither the actual world, nor the fictional world of the work, but some other world, and that those narrators tell us facts about the fictional world of the work. How can one be a fact-teller about a world one does not occupy? Alward gives us 
the example of actual people making claims about the afterlife. I don't find this a very helpful example. It's not clear that we should consider heaven, if it exists, non-actual. Think of a theist's response to a claim that since God exists outside space and time She doesn't actually exist. Rather than settle these claims, though, perhaps we can consider some less contentious examples.

It seems that we sometimes make true claims about other possible worlds, for instance when I say what would have happened if I hadn't caught the crystal goblet before it hit the concrete floor. It seems reasonable to describe this as a case of my telling you a fact (that you probably already know) about some possible world. It is a nice question how we could know about the possible (but non-actual), in part because it is a nice question what the possible (but non-actual) is, and how it is related to the actual, but it is relatively uncontroversial that we do know something about the possible. We can thus make sense of a possible person telling some fact about some world other than the one he inhabits. I might tell you that if I had been illustrating counterfactual claims in a possible world where I failed to catch the glass, I would have used a different counterfactual in my illustration. That possible person (my counterpart) would have thus been saying something about a different possible world than the one he inhabits. This is perhaps a less controversial example, then, of a non-actual teller of facts about a world he doesn’t occupy. So, I agree with Alward that such narrators are possible in principle.

Let us now turn to fiction. It's easier to see how we can make true claims about the fictional, as opposed to the possible, since it's easier to see how the fictional is rooted in the actual. Somehow, by writing certain things down in a certain situation (or saying things, or throwing shadows on a screen, or getting images on celluloid, or whatever), 
actual people determine what is the case in some fictional world. This is uncontroversial, I take it. We implicitly understand roughly how this works, and thus we can report true claims about fictional worlds, such as that Wilson is in Africa. In a sense, then, we might say that I tell you a fact when I tell you that Wilson is in Africa, though it is a fact about a fictional world, just as I tell you a fact about a possible world when I tell you what would have happened had I not caught the goblet. But this is not the kind of fact-telling that Alward has in mind. He is contrasting fact-telling to fiction-telling, which is what actual authors and some fictional characters do. This makes it difficult to see what his nonactual tellers of facts about fictional worlds are doing, though. It is true, as Alward says, that one can tell facts about worlds other than the actual world, but there are two very different kinds of things going on depending on whether the world being described is possible or fictional. Moreover, it is unclear what relation holds between the world of his non-actual, non-fictional narrators and their respective fictional worlds. Thus there seems to be at least an equivocation in his argument. If it is the sense in which we can tell facts about fictional worlds that is relevant, Alward's non-actual, non-fictional fact-telling narrators are otiose. Authors are unimpeachably positioned to tell us the facts about the fictional worlds they create. But if it is the sense in which we can tell facts about possible worlds that is relevant, Alward's argument is unsound. For there is no reason to suppose that there are some non-actual beings 'out there' somewhere who are epistemically related to fictional worlds the way we are epistemically related to possible worlds.

Let me approach this issue from one last direction. There are unproblematic fictions narrated in the first person, such as David Copperfield. Alward (like the ubiquity theorists) has no problem with saying that such novels are constructed by an actual 
author, and narrated by a fictional character. By virtue of the way the novel is constructed and the novelistic conventions we are familiar with, we take the sentences the author writes to make it the case that, fictionally, David Copperfield is telling his life story. The question is why we cannot say exactly the same sort of thing for unproblematic fictions narrated in the third-person. By virtue of the way The Heart of the Matter is constructed, and the novelistic conventions we are familiar with, we take the sentences the author writes to make it the case that, fictionally, Wilson sits on the balcony of the Bedford Hotel, his bald pink knees thrust against the ironwork. Such a theory, whereby actual authors are allowed to be narrators of their fictions, tellers of their stories, posits less ontologically and psychologically than either of the alternatives (the traditional ubiquity thesis or Alward's revised version) yet, for all I can see, does the same work. There is no reason to posit non-actual narrators in all narrative fictions, be they fictional or otherwise.

Andrew Kania

Department of Philosophy Trinity University One Trinity Place

San Antonio, Texas 78212

akania@trinity.edu 


\section{Notes}

${ }^{1}$ Peter Alward, “For the Ubiquity of Non-Actual Fact-Telling Narrators: A Reply to Kania,” Journal of Aesthetics and Art Criticism ?? (200?): ???-??; Andrew Kania, “Against the Ubiquity of Fictional Narrators,” Journal of Aesthetics and Art Criticism 63 (2005): 47-54. Parenthetical references are to Alward’s piece.

${ }^{2}$ Alward's example of such a theory is Jerrold Levinson's hypothetical intentionalism. For the record, Levinson resists this characterization of his theory. He maintains that it is the best hypothesis of the semantic intentions of the actual author (given certain restrictions) that determines the core meaning of a work, not the intentions of some hypothetical author. (See, for example, "Hypothetical Intentionalism: Statement, Objections, and Replies” in Is There a Single Right Interpretation? ed. Michael Krausz [Philadelphia: The Pennsylvania State University Press], pp. 312-13, 316.) Nonetheless, there are other theories of interpretation that appeal to such hypothetical or implied authors (for example, Alexander Nehamas, “The Postulated Author: Critical Monism as a Regulative Ideal,” Critical Inquiry 8 (1981): 133-149), and familiarity with the idea is all that is required for the purposes of Alward's argument.

${ }^{3}$ I ignore story-telling narrators throughout. I discuss them to some extent in "Against the Ubiquity of Fictional Narrators”.

${ }^{4}$ At least, I hope this is an acceptable gloss on a part of Kendall Walton's theory in Mimesis as Make-Believe: On the Foundations of the Representational Arts (Cambridge, MA: Harvard University Press, 1990). This claim does not depend on Walton's particular theory of fiction, however. Any other understanding of fictional beings is likely to make 
implied authors fictional (though, to be sure, not part of the world of the work, narrowly construed).

${ }^{5}$ I say 'seem’ because there is an ambiguity here, as I discuss below.

${ }^{6}$ Walton, Mimesis as Make-Believe, p. 145. Again, something like this principle is to be found in many different theories of fiction. In addition to the references in Mimesis as Make-Believe, see Gregory Currie, The Nature of Fiction (Cambridge: Cambridge University Press, 1990), pp. 52-98.

${ }^{7}$ Walton, Mimesis as Make-Believe, pp. 150-61.

${ }^{8}$ Paul Grice, "Logic and Conversation," in Syntax and Semantics, vol. 3 (Speech Acts), ed. Peter Cole and Jerry L. Morgan (New York: Academic Press, 1975), p. 45.

${ }^{9}$ This generalizes Grice’s principle (“Logic and Conversation”, p. 45) by the substitution of 'linguistic' for 'conversational' and 'discourse' for 'talk exchange'.

${ }^{10}$ Walton, Mimesis as Make-Believe, pp. 150-61. 